\title{
Decadence and Mass Culture: The Novel as a Panorama. The Case of Bruges-La-Morte*
}

\author{
Eduard Cairol \\ Universitat Pompeu Fabra, Barcelona, Spain
}

\begin{abstract}
Today's idea of the so-called fin-de-siècle is still somewhat inexact and incomplete. This lack of precision originates from a deeply rooted methodological approach which consists of considering the respective developments of literature, art, and science in isolation, without paying attention to any interference or reciprocal contamination. This defective method also affects the overlaps and contacts between high culture and popular culture. Despite the progress made over recent years, there are few researchers who approach their objective with a real awareness of the complexity of a time period which saw the appearance of mass culture in the current sense and an unprecedented boom in scientific and technological development. ${ }^{1}$ To this end, the example of the great German philosopher Walter Benjamin and his studies on Paris during the 19th century-collected in the essays on the great French poet Charles Baudelaire and especially in the monumental and unfinished work The Arcades Project-is, without doubt, a model to follow. Taking the path suggested by Benjamin, this article sets out a revision of the novel Bruges-la-Morte (1892) by the Belgian writer Georges Rodenbach, considered one of the major exponents of the fin-de-siècle decadence, which goes beyond the usual approach of a symbolist reading, by paying special attention to the frictions between literature and technology on one hand, and between literature and popular entertainment on the other.
\end{abstract}

Keywords: fin-de-siècle, mass culture, Walter Benjamin, Georges Rodenbach, Bruges-la-Morte, symbolism, decadence, literature and technology

There is an abundant literature whose stylistic character forms an exact counterpart to dioramas, panoramas, and so forth.

-W. Benjamin

The Arcades Project

Contemporary with the panoramas there was a panoramic literature.

W. Benjamin

Paris, the Capital of the Nineteenth Century

\footnotetext{
* Acknowledgments: This paper is supported by the Spanish Ministry of Economy and Competitiveness (Grant HAR2013-48050-P).

Eduard Cairol, Philosophy doctor, Associated Professor, Department of Humanities, Universitat Pompeu Fabra.

${ }^{1}$ An exception to this rule is the exemplary account of the age by Hermann Broch (1955), Hofmannsthal und seine Zeit. In Dichtung und Erkennen (Poetry and Knowledge), Frankfurt: Suhrkamp.
} 


\section{Introduction}

Several novels published around 1900 have been considered, by different authors, as "the Bible of Decadentism”. Beside Monsieur de Bougrelon (Jean Lorrain) or À rebours (Against the Grain, J.-KHuysmans), Bruges-la-morte (Bruges-the-Dead), by Jean Lorrain, has been also purposed for this title of honour. A true best-seller of its age, Bruges-la-morte is only one else among a constellation of novels consecrated to the topic of "the dead City", like for instance The Death in Venice (Th. Mann) or La Regenta (Leopoldo Alas, “Clarin”). But even far away of this common place of the End of the Century, Rodenbach's novel introduces some other subjects of interest more, specifically those concerning its relationship with modern forms of entertainment and the new techniques of perception. According to this hypothesis, Bruges could be seen not only as a ruin of a lost age but as an essay of a new literary genre for a new time, and even a premonition for future experiences of approaching between high and low culture.

\section{Bruges-la-Morte and the Decadent Sensibility}

Bruges-la-Morte, written in French by the Belgian writer Georges Rodenbach (1855-1898) and published in 1892, presents a story line that interweaves a love story, a crime novel, and a horror story all in poetical prose. It is an example of the hybridisation of genres which since Baudelaire has been considered characteristic of the decadent period in general and of the fin-de-siècle in particular (Calinescu, 1991, p. 163). A man heartbroken by the early and sudden death of his wife seeks refuge in the declining city of Bruges with only one purpose; that of living in its phantasmagorical cityscape with the spectres of his memories. There he meets a young woman who bears a mysterious resemblance to his lost love. She becomes his lover until he-faced by the impossibility of resurrecting a past which is lost forever-brutally murders her.

As can be observed, echoes of the North-American writer Edgar Allan Poe are more than perceptible in the novel. His influence both on European fin-de-siècle literature in general and on the Symbolist Movement in particular, thanks to the translations and critical essays by Baudelaire, has been amply commented on. ${ }^{2}$ Subjects such as the pain caused by the death of loved ones, the inevitability of death or the illusion of returning from the afterlife all possess an unmistakable air of Poe. ${ }^{3}$ No less attributable to Poe is a remarkable capacity for recreating desolate settings which reflect the mood of the main character (a prime example being The Fall of the House of Usher), as well as the importance given to the city as a backdrop to the events narrated in the story. ${ }^{4}$ In our case, this role is assigned to the Flemish city of Bruges, for centuries prostrated in a state of semi-abandonment, seemingly at the margins of history, with its canals of murky water slowly and silently moving between ancient, sleeping houses.

Thus, Bruges constitutes the perfect stage for the reliving of memories and even for the evocation of death and wasting away. As the French phenomenologist Gaston Bachelard pointed out in his study L'eau et les rêves,

\footnotetext{
${ }^{2}$ See the selection of texts documenting the influence of Poe through the French translations by Baudelaire, Mallarmé, and Valéry, chosen by Antoni MARÍ (Ed.) (2011), Matemática tiniebla. Genealogía de la poesía moderna (Mathematical Darkness. Genialogy of Modern Poetry), Barcelona, Galaxia Gutenberg.

${ }^{3}$ For Edgar Poe's themes and their subsequent influence on the decadent aesthetics, see Mario Praz, Il patto col serpent (The Pact with the Snake), Milan, Leonardo, 1995, pp. 46-126.

${ }^{4}$ Obviously, the theme of the city as a literary character in general terms cannot be discussed here because of its extension and complexity.

Nevertheless, the role of the cities in the more specific context of the decadent literary works has been discussed in the study of Jean Pierrot (1977), L'imaginaire decadent (The Decadent Imaginary) (1880-1900) pp. 210-214.
} 
water is the perfect incarnation of death for the material fantasies of writers and poets. ${ }^{5}$ According to Bachelard, delivery to the waters of a sea or river appears to have historically been the first method of disposing of the dead (recalling a return to our origins, as much for the species as the individual; whether to the bosom of the primeval ocean or to the placenta filled with amniotic fluid), in the hope of a future rebirth. In this sense, water is both an image of death and of a return to life, fitting in perfectly with the themes of the novel (Bachelard, 1942, p. 87). More specifically for Bachelard, stagnant and slow-moving waters incarnate fantasies and dreams of a longed-for death, presented as a welcoming end to earthly suffering and providing a long-awaited reunion with departed loved ones. He places this fantasy firmly under the tutelage of Ophelia, a character from Shakespeare's tragedy Hamlet who, while weaving long garlands of flowers, drowns herself in a slow-moving river (Bachelard, 1942, pp. 95-98).

The distinguished French scholar also points to the possibility of the imagination of matter performing the process of cosmisation in which diverse objects from nature appear integrated into the metaphorical sphere, thus amplifying the effect of the original. In this specific case, Bachelard refers to an opheliaisation of nature in the image of the moon reflected in the water, gently rocking as if it were the drowned woman. In accordance with this, in Rodenbach's novel we witness a process of cosmisation or more precisely one of opheliaisation, in which the entire city of Bruges appears as a materialisation of fantasies of death, self-destruction, and return to life generated in the mind of the main character by the memory of his dead lover (Bachelard, 1942, pp. 103-105). Rived with canals of dark and sluggish water, bristling with spires harking back to an age of splendour irredeemably lost, shrouded in fog and inhabited by spectral figures walking alone through empty streets, Bruges becomes the perfect image of decadence and death. As such, it goes well beyond the simple role of a projection of the obsessions of the main character, Hugues Viane. As pointed out by Patrick Laude in a remarkable book, Viane's outlook appears as a prototype of the mind-set and world-view of the decadents. ${ }^{6}$ For this mind-set, the course of history-with its exponential rate of transformation and change, of agitation and frenzy, and of aggression and vulgarity... - is following a path fatally heading for decadence and, finally, its own stagnation. ${ }^{7}$ In the face of such a path it is better to step outside the course of time and to take refuge in an ivory tower, to avoid the perils of decadence represented by the putrid waters (Laude, 1990, pp. 42-43).

For his part, in another highly recommendable text filled with interesting suggestions, the eminent Hans Hinterhäuser has noted the not unintentional abundance of dead cities in the fin-de-siècle imagination. ${ }^{8}$ Among the examples given by the author are the French town of Aigües Mortes, Toledo in Spain and Venice in Italy, this last in the process of disappearing beneath the waves, as well as the old city of Prague and Bruges itself... As the author perceptively points out, all these cities share a certain suitability as candidates for images of decadence, after having been side lined from history and from the fascinating beauty of death. These two traits

\footnotetext{
${ }^{5}$ See from Gaston Bachelard (1942), L'eau et les rêves. Essai sur l'imagination de la matière (The Water and the Dreams. Essay on the Imagination of the Material), in the pages 88-90.

${ }^{6}$ See from Patrick Laude (1990), Rodenbach. Les décors du silence (Rodenbach. The Sceneries of Silence), pp. 34, 76. For later and more precise information on the decadent outlook and psychology, see the already classical study by Guy Michaud(1961), Message poétique du Symbolisme (Poetical Message of Symbolism), specifically the chapter titled Les Décadents, ou le mal de fin de siècle (The Decadents or the Sickness of the End of the Century), pp. 235-271. See also the work of Jean Pierrot, L'imaginaire decadent (The Decadent Imaginary), pp. 61-101.

7 For the topic of decadence and History, see the book of: Pierre Chaunu (1981), Histoire et decadence (History and Decadence).

${ }^{8}$ See from Hans Hinterhäuser (1998), Fin de Siglo. Figuras y Mitos (End of the Century. Characters and Myths), p. 64.

The most authoritative study on the subject of dead cities is, however, the book of Donald F. Friedman (1990), The Symbolist Dead City: A Landscape of Poesis.
} 
allow them to be identified with the mind-set of an age characterised by nostalgia for a past, a transcendental time, in which — again pointed out by Patrick Laude (1990, p. 34) - the human being was still in possession of a key to understanding, today lost, devastated by the clamour of the modern world and buried under the avalanche of change and transformation brought on by modernity. But the image of the dead city turns in on itself and implies, in this interpretation, closure or seclusion into an interior space on one hand, and into silence on the other. Certainly, sleepy cities with frequently deserted streets, like Bruges, allow public space to be seen as an extension of private space or the domestic interior. The decadent mentality, faced by the strife of the exterior world, looks for its refuge in them. For its part, this silence could even appear as a reflection of the silence of God to be found in the so-called negative or apophatic schools of theology, ${ }^{9}$ among which figures the mysticism developed in the convents of beguines (lay women devoted to God) some of which are still preserved in the city of Bruges today.

\section{Dead Cities in fin-de-siècle Literature}

Jean Pierrot, in his very interesting study of decadent imagery referred above, noted the high incidence of dead cities in the literary works of the age; in all of them, according to the author, it can be found "the dominant note, often macabre, of the decadent imagination” (Pierrot, 1997, p. 211). It can be observed, according to Pierrot, how the theme of the urban — so genuinely modern! — can also be incorporated, steeped in mystery, into the decadent world. The decadent sensibility reconciled then a taste for an urban backdrop (an artificial product, created against nature) with its characteristic preference for the morbid via the use of dead cities (Pierrot, 1997, p. 211). After the more than considerable success of Bruges-la-Morte, the Flemish city of Bruges made further appearances also in Camille Mauclair's novel Enemy of Dreams (1900) and Joris-Karl Huysmans's account of a journey around Northern Europe and Germany. The role of other cities such as Prague and Versailles (former court of the absolutist French monarchy, but later almost totally abandoned) in the general panorama of the literature of the age can also be explained in this way.

Prague, the old capital of the Holy Roman Emperor Rudolf II, still retained the aspect of a genuinely baroque city at the turn of the 19th century. As the illustrious Czech writer and academic H. Jelinek wrote (in an observation reminiscent of those other later made about Bruges), "the noise of the electric trams in one or two of its streets contrasts with the silence of its churches, convents and vast palaces patinated with the centuries" (Neruda, 1992a, p. 7). According to this author, the silence of the city's deserted small squares was evocative of the ancient vanished ages. The great chronicler of this mysterious Prague-and its accumulated memories of a dead past—is, without doubt, the poet and storyteller Jan Neruda. In his Arabesques (1864), the Czech writer revelled in the mysterious and morbid atmosphere offered by Prague at night, in particular the reflection of the moon in the waters of the river Vltava and the canals of Kampa Island alongside the Charles Bridge. When the moon shone, Prague appeared to be flooded in light. But it was "a lugubrious light, phantasmal, weak and pale, and the moon appeared as a sleeping sun” (Neruda, 1992b, p. 49). The similarity

\footnotetext{
${ }^{9}$ For obvious reasons, the complex matter of the silence of God cannot be fully developed within the limited framework of these pages. It is, however, relevant to mention specifically the mystic dimension of Belgian Symbolism and the relationship that would be established between avant-garde Belgian writers and the long tradition of Flemish mysticism. This connection was established without doubt via Maurice Maeterlinck, the first modern translator in 1895 of The Adornment of the Spiritual Marriage, the work by the Flemish mystic Jan van Ruysbroeck (translation published in Brussels in 1890). About this, see the thorough and authoritative study by Paul Gorceix (2005), Maeterlinck, l'arpenteur de l'invisible (Maeterlinck, the Archer of the Invisible), Brussels, Le Cri, p. 150-164.
} 
between this view of Prague and that of Bruges offered by Hugues Viane is more than evident. And what can be said of the celebrated Josefov or Jewish quarter, where it is said the Golem wandered, that sinister creature given life by Rabbi Loew thanks to his knowledge of the secrets of the Kabbalah? Leo Perutz, author of the novel By Night under the Stone Bridge (1926), writes about this part of the city, "With its frail houses leaning one against the other, almost in ruins [...], those sinuous alleys, full of twists [...], formed a maze in which I got irremissibly lost” (Perutz, 1991, p. 247).

Aside from Bruges and Prague, Venice is without doubt the city that takes pride of place with its mystery and sickliness in the fin-de-siècle decadent literature. Aside from the better-known Marcel Proust (Albertine Gone, 1925) and Thomas Mann (Death in Venice, 1922)—which, although chronologically speaking not being part of the fin-de-siècle, partake fully in its atmosphere-it is the French poet Henri de Régnier who best embodies this fascination for the city on the lagoon. In Esquisses vénitiennes (1906), one of his collections of stories set in Venice (together with Contes venitiennes, published in 1927), Régnier roams around the narrow streets and secondary canals of the city of the lagoon, picking out their decrepit, solitary, and morbid nature:

What quiet! Barely the flight of a passing pigeon, the zigzag of a vibrating fly, the plash of an oar in water. [...] Further on is a solitary square, encircled with yellowing and decrepit facades. In truth, such an unfavoured district! Scabrous houses in ruins reflect their tapering chimneys in a green and cloudy water way. Long-tendrilled water weeds tangle in the floating detritus. (De Régnier, 2009, p. 232)

The sense of abandonment, decadence, and neglect emanating from the scene is deeply striking. Silent, deserted labyrinthine streets, buildings from an earlier time observing us from the shadows like ghosts...

The Venice of Marcel Proust is not so very different from the decadent Venice of Régnier. The author of In Search of Lost Time, according to his own confession, also had a preference for exploring this part of the city with its humble squares and small abandoned by waters. Here, via the secondary canals, the French author could discover the human scenery of local women: match sellers, women stringing pearls, glassmakers and lace makers...-figures from a bygone time and powerfully reminiscent of the women who populated the precinct of the Beguinage in Bruges. Through the eyes of Thomas Mann Venice was also a silent labyrinth of murky waters reflecting the arabesques of the great windows of antique palaces. In their fusty air ring old melodies making it still possible to absorb the opulence of earlier times. Finally, this sensation of being beyond the present, outside real time and space, is what also overcame the Czech-born, German-writing poet Rainer Maria Rilke when he visited Toledo in $1904,{ }^{10}$ another of the fin-de-siècle dead cities, sited, according to him, halfway between the visible and the invisible worlds, the material and the spiritual.

As can be easily seen, each and every one of these spectral landscapes leads us firmly back to Bruges, the archetype of death and decrepitude, a city which is, according to Rodenbach, "the dethroned queen, who is today dying the most taciturn and moving of deaths [...] now forgotten, impoverished, all alone with her empty palaces” (Rodenbach, 2007, p. 303).

According to a description written in 1888 for the literary supplement of Le Figaro (published posthumously in the volume Évocations, 1823), like other previously handsome and wealthy cities, the Flemish nice town of Bruges also ended its days "in poverty and neglect” (Rodenbach, 2007, p. 303). Only a few monuments still bear witness to the former splendour of that city, which even Venice saluted as her own sister. Now, however, the two cities, Bruges and Venice, are twinned by their decadence. Bruges leaves the traveller

${ }^{10}$ For Rilke’s season in Toledo, see Antonio Pau Padrón (1997), Rilke en Toledo (Rilke in Toledo). 
with a "profound mortuary impression" (Rodenbach, 2007, p. 305). The houses seem abandoned and dead, while "the mutedness of sounds matches that of the colours"; thus, everything is equally dead in a city which, according to the author, is the image of death itself (la mort elle-mème) (Rodenbach, 2007, p. 305).

\section{Rodenbach and fin-de-siècle Science}

This stimulating panorama, as yet not thoroughly explored here, would not be complete if we did not attend to a series of associations which in this case lead us beyond a symbolic or mythic interpretation, ${ }^{11}$ and venture into a no less stimulating, although perhaps less explored, territory, where art and science, literary culture, and the new mass culture of large modern cities intersect. In a text which has guided our own labours, Veronique Jago-Antoine (1999, p. 233) calls our attention to the weakness and lack of robustness of a detailed analysis of the idea of Rodenbach concentrating on the waters of Bruges that ignores the complexity of what the author calls the Symbolist kaleidoscope. In this rich kaleidoscope, according to the text, there is a notable use of much less decadent and more vigorous imagery by Rodenbach, possibly inspired by his curiosity in science and technology and by his more than probable contact with members of the scientific community of the day. According to Jago-Antoine, in a group portrait painted by Théo van Rysselberghe in 1900 featuring the Belgian poet Émile Verhaeren flanked by close friends, including literary names such as Maeterlinck (but not Rodenbach alas, who had died two years before), the appearance of the eminent biologist Félix Le Dantec is not mere coincidence but indicative of a working and recognised connection between artists and scientists of that age.

As stated by Jago-Antoine, the proximity of Rodenbach to the science of his time is especially noticeable in his use of images and metaphors taken from the scientific field, specifically of a vitalist nature, especially present in his essays of literary and artistic criticism. ${ }^{12}$ There also seem to be many other fields where one may find similar traces of this influence. Paul Edwards, in another extraordinarily stimulating article, has convincingly demonstrated the presence of elements, aural as well as visual, inspired by photographic technology in Rodenbach's poetry. ${ }^{13}$ Among these elements are the use of black and white in descriptions (as in the black and white photography of the time), or the importance given to closed and interior spaces (reminiscent of a photographic camera obscura), references to water in the canals (transposition of the fluids used during the process of photographic development...), and the sound of footsteps in the silent streets of the town (inspired by the noise of the shutter when a photograph is taken). But this proximity of Rodenbach to photography presents yet more facets to be explored. Indeed, the writer's contact with Belgian literary and artistic avant-garde circles and in particular his close friendship with the Symbolist painter Ferdinand Khnopff crystallised in the illustration by Khnopff of the first edition of Bruges-la-Morte, published in 1892 (Later, after

\footnotetext{
11 "Mythic" in the sense that a scholar of religions such as Mircea Eliade was able to refer to the myths of the modern world, meaning the survival of the structures of traditional mythology and symbolism within the framework of modern secular culture. It is curious that Eliade himself identifies in the representation of Paris in literature and art one of these cases of the survival of a myth. See from Mircea Eliade (2005), Mythes, rêves et mystères (Myths, Dreams and Mysteries), pp. 21-39.

12 See from Bertrand (Ed.) (1999), Le Monde de Rodenbach (The World of Rodenbach), pp. 245-248. According to the author, Rodenbach's activity as a critic is notable for its use of images presenting the genius as a force of nature (examples being Balzac, Rodin, and Corot). Likewise, Rodenbach's preferred works (by Whistler or Puvis de Chavannes) always possessed a transformist dynamic. This catalogue of vitalist images culminated, according to Jago-Antoine's analysis, in the fusion of art and life found in the famous ballerina Loïe Fuller, highly praised by Georges Rodenbach, and whose dancing was described as un miracle d'incessantes metamorphoses (a miracle of ceaseless metamorphoses).

${ }^{13}$ Paul Edwards, Le Regne du Silence. L'esthétique photographique dans la poétique de Georges Rodenbach in J. P. Bertrand (Ed.), Le Monde de Rodenbach, pp. 29-43.
} 
Rodenbach's death, Khnopff created the scenography for the first production of Le Mirroir, a theatrical version of Bruges-la-Morte). The artist's contribution consists of the frontispiece of the book, where a female face appears adrift on the waters of the canals which from the backdrop of the picture (see Figure 1). Khnopff clearly took his inspiration in the celebrated John Everett Milais's Pre-Raphaelite work Ophelia (see Figure 2). Later he was to produce also a series of drawings likewise inspired by Bruges (see Figure 3). In this case, however, they were based on contemporary photographs of the city (see Figure 4), modified by the artist to accentuate the impression of desolation and decadence. Thus we can find disfigured monuments, squares inundated with canal waters and some clearly unrealistically deserted scenes...

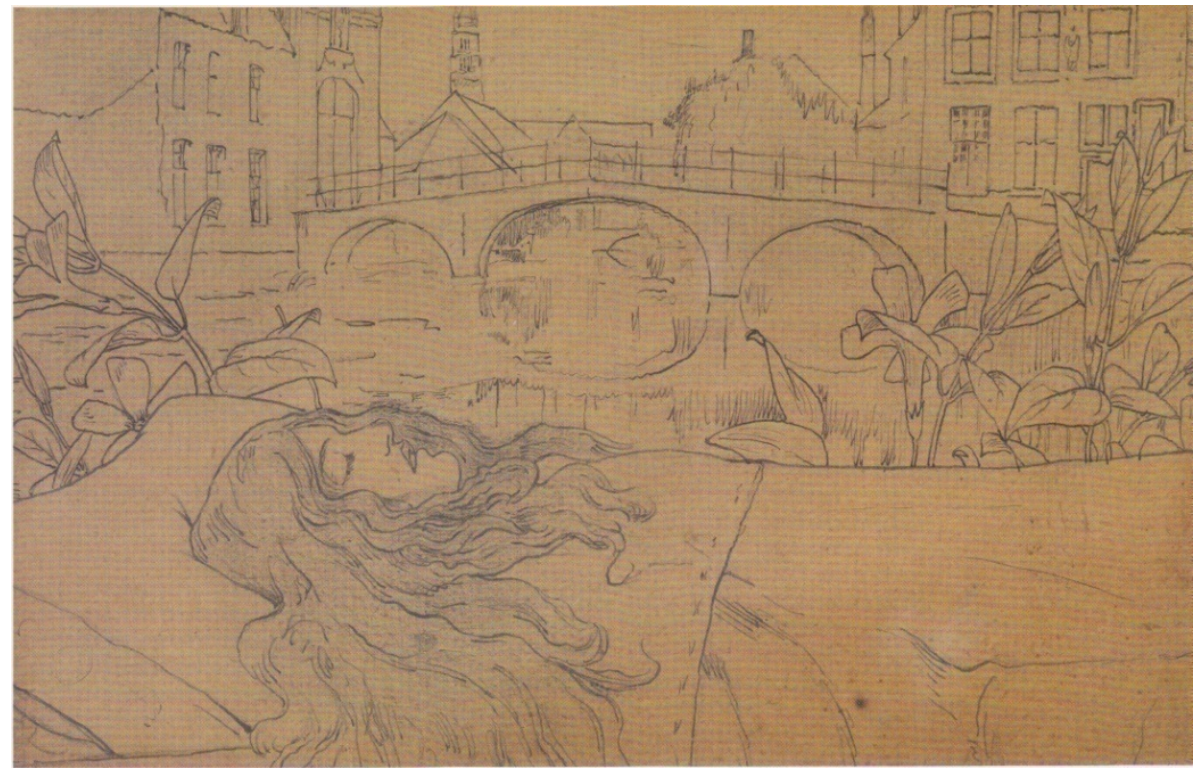

Figure 1. Frontispice by Ferdinand Khnopff for the cover of the first edition of Bruges-la-morte, published in 1892.

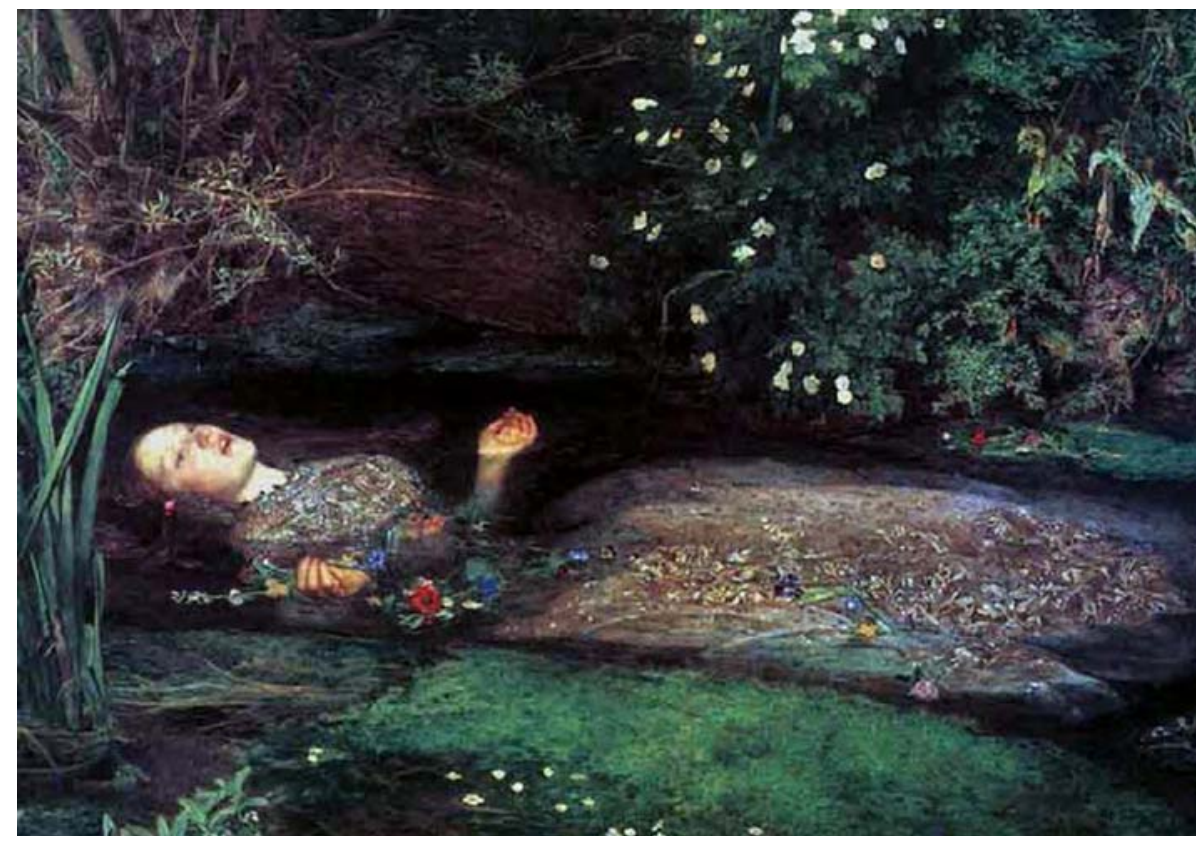

Figure 2. Sir John Everett Millais: Ophelia, 1851-1852, Oil on canvas, 110,5 x 145,8 cm., London, Tate Britain. 


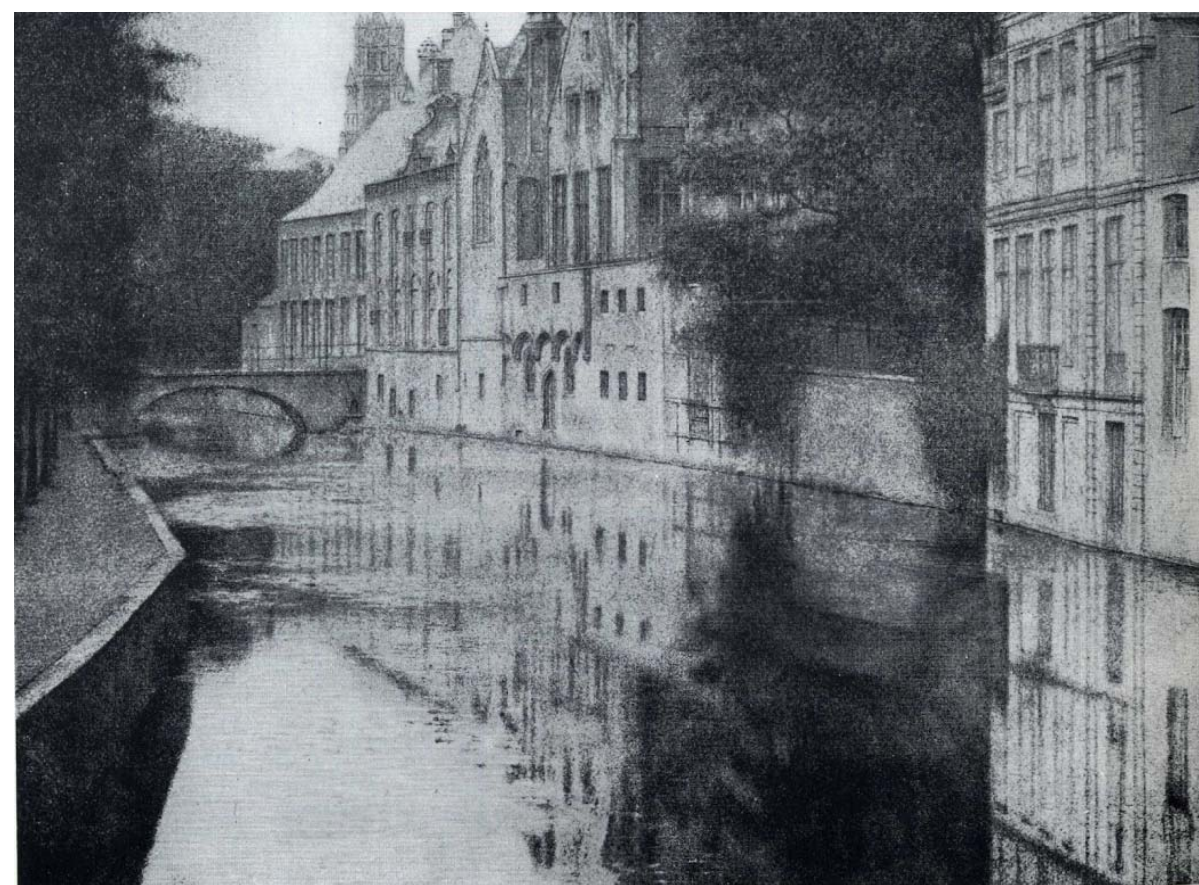

Figure3. One of the drawings of Bruges created by Ferdinand Khnopff after the photographs used by Rodenbach for the first edition of his novel. It is to observe the similitude of the drawing with the photograph below.

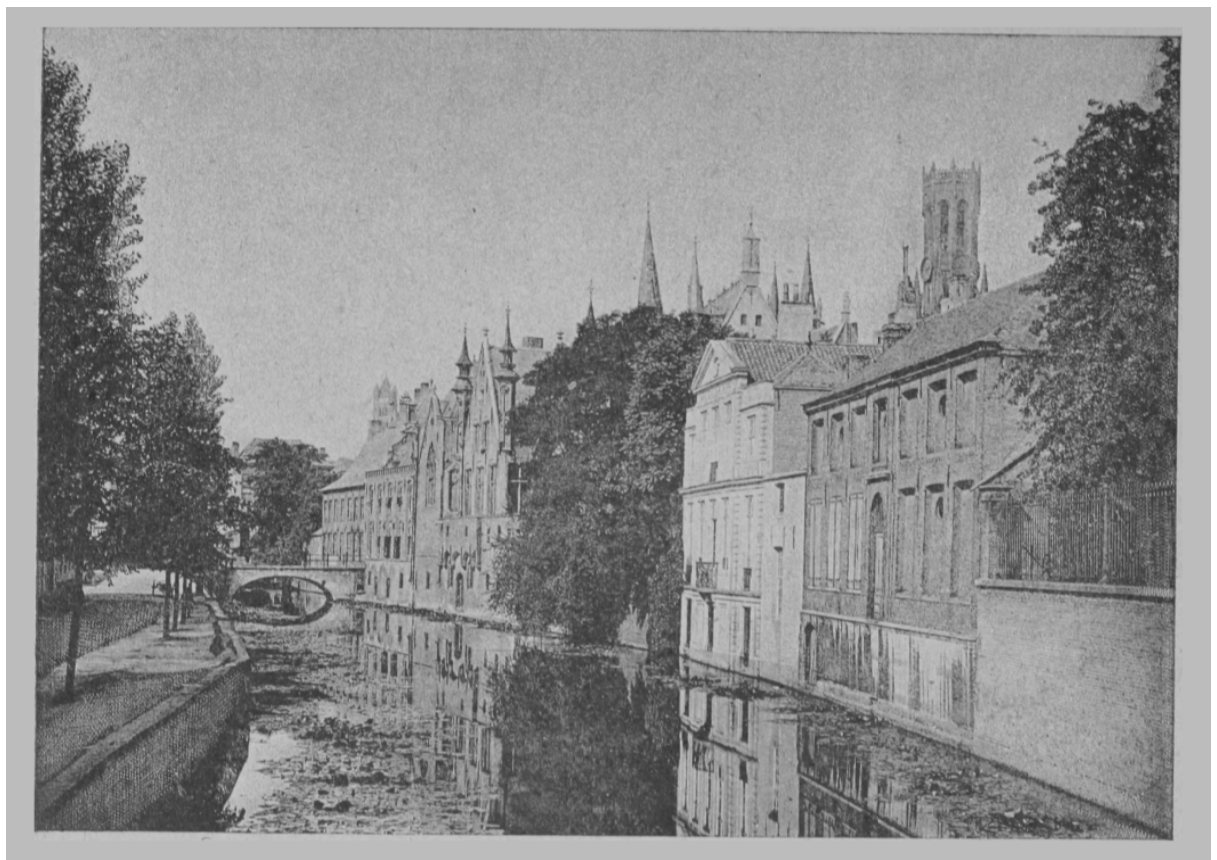

Figure 4. One of the anonymous photographs from a touristic archive used by Rodenbach to illustrate the novel from its first edition onwards.

This was by no means the first or the last time Khnopff used this approach. His frequent use of photography as a starting point and support for his own compositions is well documented. For example, in many of his portraits of his sister, he worked from previous photographs of her. This is a subject that is often relegated to the background of the general history of 19th century art, perhaps due to its controversial nature. The initial aversion shown by some artists and literary figures to photography in its infancy, as in the famous 
case of the poet and art critic Charles Baudelaire, is today very well known. ${ }^{14}$ However, the most recent research shows a general curiosity in artistic and intellectual circles of the time for the potential of this new medium for rendering and expressing reality. Even painters who publically expressed distaste for photography, such as Ingres, seemed to have resorted to it in an almost clandestine manner in their work! This can be seen as a totally natural reaction to the emergence of a radically new technology that presented so many varied uses. In any case, Khnopff's familiarity with the camera, as well as the proven link between him and Rodenbach, are enough to testify to the author's interest and involvement with the technological developments of the day and the-for our purposes, no less important—early manifestations of mass culture.

In fact, Rodenbach himself showed a very clear interest in photography (and, by association, a curiosity in technology and the rapidly popularised advances of the time) by adopting the unusual strategy of incorporating a big number of photographs of Bruges, of unknown authorship, in the text of the novel. These are in fact the photographs which inspired Ferdinand Khnopff's illustrations and which appeared in the 1892 first edition of the novel. ${ }^{15}$ Rodenbach himself justified his decision right from the book's first page, in anticipation of the surprise such a course of action would produce in the reader. According to the author himself the decision was made in response to his wish for Bruges not to appear as a mere backcloth but as another character in the novel, or even as its central character, given that its presence determines the conduct and actions of the human characters appearing in it (Rodenbach, 1998, p. 49). Rodenbach goes on to say that the reader should feel the influence of the town over their mood, as it is felt by the characters of the novel. This aim is of great significance for us in the development of our own argument.

\section{Literature, Technology and Mass Culture}

Undoubtedly, the vital enrichment of our understanding of the complex culture of the second half of the 19th century, in particular of the interferences and cross contamination between high culture, science and technology, and popular culture, in relation to the discipline and construction of the modern gaze, is owing to Jonathan Crary's insightful and superbly documented studies. He is absolutely right in presenting the deep transformations in the perception and in the reception of a world on the threshold of modernity as the combined consequence, firstly of advances in psychology, optics, and physiology, secondly of the training and discipline of the gaze brought about by modern mass entertainment, and lastly of the later lessons to be drawn from the first significant artistic avant-garde movements of the time. These all create an interaction where mere causality is overwhelmed by the interplay of often inextricable reciprocal influences. ${ }^{16}$

In this web of interrelations, Jonathan Crary focuses his attention on visual culture and leaves aside, except for the odd occasion, the field of literary studies. This was not the case for Walter Benjamin, the aforementioned German author of The Arcades Project, whose study of the cultural complexity of the second half of the 19th century appears to go hand in hand with his life-long interest in the poetry and the figure of Baudelaire (and to a lesser extent Marcel Proust). Benjamin— to whom in his studies and outlook Crary, as he frequently admits, is indebted—was indeed a pioneer in the study of the cultural production of the age, in which he combined elements of sociology, history of sciences, and archaeology of modern spectacles and

\footnotetext{
${ }^{14}$ A very good reconstruction of this polemics, can be seen in Mary Warner Marien (1997), Photography and Its Critics. A cultural History, 1839-1900.

${ }_{15}^{15}$ For further information, see from Manuel Segade (2008), Narciso fin de siglo (Narcissus End of the Century), pp. 234-235.

16 See from Jonathan Crary (1992), Techniques of the Observer. On Vision and Modernity in the Nineteenth Century, pp. 1-24.
} 
entertainment that constituted the culture of the first urban masses; all with a deep originality not exempt from, at times, spectacular effects. ${ }^{17}$ The work of W. Benjamin continues to be, even today, an inexhaustible source of pointers for new research; as much for the wealth of material it encompasses as for the complexity of the relationships it establishes between items, as well as for the occasional impression of incompleteness and precipitation of its conclusions, as if the author had not the time or inclination to develop them more fully. Among those inferences only lightly touched upon by Benjamin's genius is one which relates the modern spectacle of the panorama with the existence of a literature which he shows no hesitation in labelling panoramic. It is found in two places, or two fundamental steps, of Benjamin's work, which form part of a single line of research. They are in his 1938 essay on Baudelaire, The Paris of the Second Empire in Baudelaire (in particular, the second section, The Flâneur), and the summaries of The Arcades Book brought together under the title Paris, the Capital of the Nineteenth Century, in the first version of 1935 (there is a later 1939 version). Both texts are directly derived from his work in The Arcades Project, whose notebook Q is headed Panorama and is entirely devoted to this, then novel, form of mass entertainment. In these writings, as mentioned, Benjamin posits the possibility of a panoramic literature linked to the emergence of panoramas, which adopts some of their formal strategies.

\section{Does a Panoramic Literature Exist?}

Specifically, in the second section of Paris, the Capital of the Nineteenth Century, entitled Daguerre or the Panoramas, Walter Benjamin affirms: "Contemporary with the panoramas, is a panoramic literature" (Benjamin, 2003a, p. 35). Here, the author specifically states what had in works before The Arcades Project only been previously suggested, appearing more as tentative conjecture. Here Benjamin explores the origins of the panorama, to be found in the French Revolution of 1789. And, detecting in Balzac the literaturisation or transposition to literature of the device of the diorama, he forwards the possible existence of a so-called panoramic principle.

In a so-called panorama, the spectators viewed a painting that completely encircled them from a fixed vantage point. Against this huge and obviously extremely long painting appeared a number of figures in the foreground, standing out against the background landscape upon which were applied lighting and other effects in order to heighten the sense of reality. This relationship between figure and background is then the essence of the panorama, and is to be found at the centre of the panoramic principle. As Benjamin wrote,

To the plastically worked, more or less detailed foreground of the diorama corresponds the sharply profiled feuilletonistic vesturing of the social study, which latter supplies an extended background analogous to the landscape in the diorama. (1999, p. 531)

This is probably where Benjamin is most explicit in his description of the workings of a panorama. However, here the emphasis of his exposition falls-as opposed to the more or less detailed working of the foreground...- - on the social study corresponding to the background of the scene. Or at least this is what may be understood from the subsequent development that the subject receives from the author. Hence in the same entry of The Arcades Project where Benjamin establishes the existence of a literary genre whose stylistic character

\footnotetext{
${ }^{17}$ A good measure of the wealth of material dealt with by Benjamin is available in the subtle and very well-documented analysis by Susan Buck-Morss (1989), The Dialectics of Seeing in W. Benjamin The Arcades Project. Further information is to be found also in some papers by the same author, published between 1981 and 1995, and collected in: Susan Buck-Morss (2005), Walter Benjamin, escritor revolucionario (Walter Benjamin, Revolutionary Writer).
} 
forms "an exact counterpart to the dioramas, panoramas, and so forth" (Benjamin, 1999, p. 531), he cites as examples nothing more than feuilletons and series of moral sketches that appeared in the mid-19th century, such as The French as Painted by Themselves and others since "in a certain sense they are moral dioramas" (Benjamin, 1999, p. 531). Here is where the reference to Balzac and his series of novels La Comédie humaine would have its proper place. In the summary of his magnum opus Paris, the Capital of the Nineteenth Century (first version), Benjamin refers more explicitly to feuilleton writers such as Giraradin and others, and a supposed informational base that functions-being as the writer says "technically constructed" (Benjamin, 1999, p. 531) — like the painted background of a panorama to which he attributes, at least in part, a social character.

This view regarding the possibility of a panoramic literature will establish not only references to works cited in its defence, but above all the practical identification of this possible literary genre with the so-called physiologies of that time (Benjamin, 2003b, p. 18). These are the vast perspectives, according to Benjamin, whose informative wealth corresponds to what in the previously cited work on Baudelaire is called the analysis of types, where there was, from the bustle of the boulevard to the fenced-off world of opera boxes, "not a figure of Paris life that was not sketched by the physiologue” (Benjamin, 2003b, p. 18). Thus it can be taken that the history of panoramic literature (like that of the feuilleton and especially of physiologies) peaked around 1840 and ended, according to Benjamin, a few years later. Obviously all this does not allow for the establishment of any parallels with Bruges-la-Morte, a novel published in 1892 and which presents, as we have already seen, a structure whose peculiarity resides in apportioning the entrancing Flemish cityscape the unusual role of protagonist. But, in any case, in the texts by Benjamin devoted to this question there are still some other aspects that also warrant a more detailed inspection.

Thus, the author of the brief essay The Paris of the Second Empire in Baudelaire touches on, in this very text, the existence of a group of physiognomies assigned, along with those of nations and animals, to cities (Benjamin, 2003b, p. 18). Of course, this observation would appear to be highly valuable for our line of reasoning. It is true that the examples suggested by Benjamin-Paris à table, Paris dans l'eau, Paris à cheval — do not seem to be at all related to literature in the true sense, but they do at least point to the possibility of the city as such occupying at some time the backdrop to narrated events which in the mechanism of the panoramas would correspond to the landscape. However, Benjamin does not accord here any special treatment to the physiognomies of the city and places their disappearance chronologically in the same years as the rest of the physiological genre. Nevertheless, for him there does appear to be an explanation for this fact. It is the parallelism or harmony between the intermittent character of such descriptions and the "habitual walk of the flâneur who goes botanising on the asphalt” (Benjamin, 2003b, p. 19), in Benjamin's celebrated phrase. According to Benjamin's well-known analysis, the characteristic wandering of the flâneur ceased to be possible in the city of Paris (except inside the arcades) due to Haussmann's city planning project which offered the pedestrian a too little protection against the constant traffic of carts and carriages along the wide avenues now opened through the narrow streets of the old town. ${ }^{18}$

But, what is the real reason for this relationship? What characterises the wandering of the flâneur? For Benjamin (2003b, p. 45) it is the-apparently so dark—fact that the flâneur does not want to give up his

\footnotetext{
${ }^{18}$ For a subtle, perspicuous approach to this topic, see the extraordinary book of Marshall Berman (1983), All That Is Solid Melts Into Air. The Experience of Modernity, pp. 158-159. For further information about the deep transformations of the city of Paris around 1850, see also David Harvey (2006), Paris, capital of modernity.
} 
privacy. And what does he really mean by this? That since the arcades of Paris, last refuge of the flâneur, are intermediaries between the street and the interior, and the art of the feuilleton consists also of transforming the boulevard into an interior-again according to Walter Benjamin — "the street became a dwelling place for the flâneur, he is as much at home among house facades as a citizen is within his four walls” (Benjamin, 2003b, p. 19). Nevertheless, it is precisely this which, after a certain point (coinciding with the flâneur taking refuge in the covered arcades, the decline of the feuilleton and of the physiologies, as well as of the genre of panoramic literature), had become impossible in Paris as a consequence of Haussmann's radical urban transformations, and which, in a small provincial city like Bruges, anchored in its mediaeval past without recognising (just like, according to Benjamin, the flâneur) the new pace of progress and modernity, remained an actual possibility, not to say the most natural way of experiencing urban space. But this is not only a supposition of ours, however logical it may be. Rodenbach himself subscribed to it. For example, he writes in his novel of the visit of Barbe, the central character's old servant, to one of the well-known beguinages in the city, an authentic mediaeval enclave in the urban area, where the time of modernity seems to have been detained.

Finally, the close association between the city of Bruges and the flâneur's wandering is made explicit beyond all doubt, not in Rodenbach's novel but in another piece he wrote about this town. It is part of his journalistic oeuvre, specifically from a series that appeared in the literary weekly magazin Figaro and that was posthumously published in the collection Évocations (1923). It is an article, appeared on 16 June 1888, dedicated to Flemish Bruges, in which the author describes the joy of strolling through the city at the speed of a "slow wander" (lente flânerie) (Rodenbach, 2007, p. 304).

\section{Bruges-la-Morte: A Panoramic Novel}

Thus, in conclusion, the scenery of Bruges did not only still allow for the peculiar kind of wanderings of a flâneur, but was even perfectly in tune with such wanderings due to being dead and outside the course of time. The city did not exclude, quite to the contrary; we can say that it enabled, the survival of the literary genre (then already extinguished in France) of the physiology of cities as an example of panoramic literature where the urban landscape acts as a backdrop to the leading figures of the story narrative! However, the most surprising thing of all is maybe that this way of moving around the city so characteristic of the flâneur and which—we must not forget it-results in experiencing urban space as though it is domestic space, is also, for Benjamin, a characteristic of the effect caused by panoramas. Indeed, according to one of his notes in The Arcades Project, "the interest of the panorama is in seeing [...] the city indoors" (Benjamin, 1999, p. 532). And we should not forget that—as Benjamin himself pointed out—the so-called bourgeois interior is one of the important loci of the end of the 19th century; a place where bourgeois intimacy and fantasy could still resist the onslaught of the professional and the public spheres. Hence, as already shown by specialists in the period, Symbolist novels frequently feature individuals whose withdrawal and seclusion from the modern world is a significant characteristic of their lifestyle (Laude, 1990, p. 117). And, lastly, we should also not forget that-as has frequently been stated - the backdrop of Bruges as characterised in Rodenbach's work is really nothing other than, for its undisturbed peace and quiet, an interior projected onto the urban space! $!^{19}$

This conclusion- that is to say the inclusion of Bruges-la-Morte in the literary category of the panoramic

\footnotetext{
${ }^{19}$ An excellent analysis of the role of space in the novels of Rodenbach is to be found in the detailed study by Marco Modenesi (1996), Il malinconico incantesimo. La narrativa di Georges Rodenbach (The melancholic Charm. The Narrative of Georges Rodenbach), pp. 58-78.
} 
literature - is in fact supported by a series of new observations, in this case from Benjamin himself. Furthermore, these observations have the virtue of projecting the notion of panoramic literature far away from the sociological realm (and the analysis of human types), where we had provisionally sited it in accordance with the author of The Arcades Project, towards something like a literature of landscape in which the city is the protagonist (in fact, much more directly relatable to the workings of a panorama...), and in which it would not be problematic to include Bruges-la-Morte. Thus, in the prolix notebooks that constitute his major work, Benjamin furnishes us with historical examples of panoramas, such as that one opened in Paris for the 1900 Universal Exhibition, fittingly named Le tour du monde, where the public could admire an Indian gallery, a pagoda, a Chinese tower, and so forth...; or the one presented by Daguerre after the 1830 revolution including a view of la Place de la Bastille on 28 July of the same year (Benjamin, 1999, p. 534). They all have a landscape, in some cases unmistakeably urban, as their backdrop (as it happens also in Rodenbach's novel). And, when the author describes with details one of "the old dioramas, nested in the arcades" (Benjamin, 1999, p. 533) of Paris..., he revealingly writes: "Seraglios were mirrored on moonlit waters; bright nights in deserted parks loomed large” (Benjamin, 1999, p. 533). In conclusion, "It was an ingenious experiment on the moonstruck, magic night...” (Benjamin, 1999, p. 533). Obviously, this is a scenery which corresponds extraordinarily well with Rodenbach's descriptions of Bruges, where the continual presence of sluggish water in the old canals gives rise to the above mentioned speculations on the opheliaisation of the city.

\section{Conclusion}

So, what would appear to be absolutely certain is then a close relationship between the panoramic principle and the existence of a backdrop with landscape. Certainly, when Benjamin attempts to project this principle onto the field of literature, the place that corresponds to this backdrop would seem to be occupied —owing, perhaps, to his own primary concerns stemming from his involvement with Marxism...-by a sort of human or social landscape. However, the task of our research has mainly consisted in demonstrating how — via the figure of the flâneur and elements such as the category of interieur — a reference to a backdrop of landscape is never for a single moment far from the author's mind.

This squares perfectly not only with Bruges-la-Morte, but also with a whole series of works from more or less the same period that all feature the presence of urban landscapes (Venice, Toledo, Prague...), which interact with their narrative lines as a powerful influence upon the main characters. Thus, these works reproduce the actual structure of panoramas; spectacles where the background landscapes become to all intents and purposes the main focus (as opposed to being mere scenery), reversing the customary relation between figure and background, and thus giving rise to a specific genre that may justifiably be named panoramic literature.

Lastly, Walter Benjamin's inviting suggestion "to reflect rigorously on the particular pathos that lies hidden in the art of the panoramas” (Benjamin, 1999, p. 529), was perhaps not taken up by its own author in the most rigorous way. Or it may be this would only seem to be the case. Indeed, the continual comparison between panoramas and the cinema in The Arcades Project may throw unexpected light on the pertinence of our own interpretation. As has been persuasively argued, Bruges-la-Morte was to witness its own resurrection in Alfred Hitchcock’s film Vertigo (1958). ${ }^{20}$ In this way, the relationship between an icon of Symbolism (Rodenbach

\footnotetext{
${ }^{20}$ We are referring to the paper of Ana González Salvador, "De la ressemblance: Georges Rodenbach/Alfred Hitchcock" (On resemblance: Georges Rodenbach/Alfred Hitchcok), in J. P. Bertrand (Ed.), Le monde de Rodenbach (The world of Rodenbach), pp. 105-118.
} 
and his novel) on one hand, and technology and nascent mass culture on the other could finally be revealed in all its glory.

\section{References}

Bachelard, G. (1942). L'eau et les rêves. Essai sur l'ima-gination de la matière (The water and the dreams. Essay on the imagination of the material). Paris: Corti.

Benjamin, W. (1999). The arcades project. (H. Eiland \& K. McLaughlin, Trans.). Cambridge \& London: Harvard University Press.

Benjamin, W. (2003a). Selected writings, vol. 3, 1935-1938. (E. Jephcott \& others, Trans.) Cambridge \& London: Harvard University Press.

Benjamin, W. (2003b). Selected writings, vol. 4, 1938-1940. (E. Jephcott \& others, Trans). Cambridge \& London: Harvard University Press.

Berman, M. (1983). All that is solid melts into air. London: Verso.

Bertrand, J. P. (Ed.). (1999). Le monde de Rodenbach (The world of Rodenbach). Brussels: Labor.

Broch, H. (1955). Dichtung und Erkennen (Poetry and knowledge). Frankfurt: Suhrkamp.

Buck-Morss, S. (1989). The dialectics of seeing. In W. Benjamin, The arcades project. Cambridge \& London: MIT.

Buck-Morss, S. (2005). Walter Benjamin, escritor revolucionario (Walter Benjamin, revolutionary writer). Buenos Aires: Interzona.

Calinescu, M. (1991). Cinco caras de la modernidad: Modernismo, vanguardia, decadencia, kitsch, post-modernismo (Five sides of the modernity: Modernism, avantgarde, decadence, kitsch, post-modernity). Madrid: Tecnos.

Chaunu, P. (1981). Histoire et decadence (History and decadence). Paris: Perrin.

Crary, J. (1992). Techniques of the observer. On vision and modernity in the ninetheen century. Massachusetts: MIT.

Eliade, M. (2005). Mythes, rêves et mystères (Myths, dreams and mysteries). Paris: Gallimard.

Friedman, D. F. (1990).The symbolist dead city: A landscape of poesis. New York: Garland.

González, S. A. (1999). De la ressemblance: Georges Rodenbach/Alfred Hitchcock (On resemblance: Georges Rodenbach/Alfred Hitchcok). In J. P. Bertrand (Ed.), Le monde de Rodenbach (The world of Rodenbach). Brussels: Labor.

Gorceix, P. (2005). Maeterlinck, l'arpenteur de l'invisible (Maeterlinck, the archer of the invisible). Brussels: Le Cri.

Harvey, D. (2006). Paris, capital of modernity. New York: Rout-ledge.

Hinterhäuser, H. (1998). Fin de Siglo. Figuras y Mitos (End of the century. Characters and myths). Madrid: Taurus.

Laude, P. (1990). Rodenbach. Les décors du silence (Rodenbach. The scenaries of silence). Brussels: Labor.

Marí, A. (Ed.) (2011). Matemática tiniebla. Genealogía de la poesía moderna (Mathematical darkness. Genealogy of modern Poetry). Barcelona: Galaxia Gutenberg.

Michaud, G. (1961). Message poétique du symbolisme (Poetical message of symbolism). París: Nizet.

Modenesi, M. (1996). Il malinconico incantesimo. La narrativa di Georges Rodenbach (The melancholic charm. The narrative of Georges Rodenbach). Milano: Università Cattolica del Sacro Cuore.

Neruda, J. (1992a). Escenas y arabescos (Scenes and Arabesques). Barcelona: Editorial Juventud.

Neruda, J. (1992b). Imágenes de la vieja Praga (Images of the old Prag). Barcelona: Editorial Juventud.

Pau Padrón, A. (1997). Rilke en Toledo (Rilke in Toledo). Madrid: Trotta.

Perutz, L. (1991). De noche bajo el puente de piedra (By night under the stone bridge). Barcelona: Muchnik Editores.

Pierrot, J. (1977). L'imaginaire decadent (1880-1900) (The Decadent Imaginery). Paris: PUF.

Praz, M. (1995). Il patto col serpente (The pact with the snake). Milano: Leonardo.

Proust, M. (1999). À la recherche du temps perdu (In search for the lost time) .Paris: Gallimard.

Rodenbach, G. (1998). Bruges-la-morte (Bruges-the-dead). Paris: Flammarion.

Rodenbach, G. (2007). Les essais critiques d'un journaliste (The critical essays of a journalist). Paris: Champion.

Segade, M. (2008). Narciso fin de siglo (Narcissus end of the century). Barcelona: Melusina.

Warner Marien, M. (1997). Photography and its critics. A cultural history, 1839-1900. Cambridge: Cambridge University Press. 